\title{
SYSTEM OBSŁUGI GWARANCYJNEJ ŹRÓDŁEM KIERUNKÓW DOSKONALENIA SYSTEMU ZARZĄDZANIA JAKOŚCIĄ OKIEN PCV
}

\begin{abstract}
Streszczenie: Jednym z podstawowych warunków, prawidłowego funkcjonowania przedsiębiorstw, jest istnienie systemu obsług: gwarancyjnych i pogwarancyjnych klientów w zakresie dostarczanych wyrobów. Uzyskane dane z funkcjonowania tego systemu, mogą być źródłem doskonalenia systemu zarządzania jakością wyrobu, w tym przypadku okien PCV. Niniejszy artykuł przedstawia dane pozyskane z tego systemu a dotyczące przyczyn i skutków niezgodności tego wyrobu.
\end{abstract}

Słowa kluczowe: okna PVC, jakość, gwarancja, rękojmia

\section{Uwarunkowania prawne w zakresie świadczeń gwarancyjnych}

W celu przybliżenia regulacji prawnych w zakresie świadczeń gwarancyjnych podjęto próbę udzielenia odpowiedzi na kilka podstawowych pytań:

1. Kto może być gwarantem?

Obowiązkiem świadczeń gwarancyjnych może być objęty: producent, dystrybutor, sprzedawca i importer.

2. Jak dlugi może być czas gwarancji?

Czas ten zależy od woli gwaranta (obecnie jest to jedno $\mathrm{z}$ narzędzi walki konkurencyjnej). Spotyka się okresy gwarancji rocznej ale też wieloletniej. Jeżeli jednak w deklaracji gwarancyjnej brak jest określenia długości tego okresu, wówczas przyjmuje go jako okres dwuletni.

Okres gwarancji w określonych przypadkach może biec od nowa, na przykład w przypadku wymiany towaru na nowy lub też dokonania istotnych napraw. Możliwe są tutaj inne rozwiązania zależne od woli gwaranta.

3. Jaki może być zakres odpowiedzialności gwaranta?

Zakres ten jest dobrowolny $\mathrm{i}$ reguluje go deklaracja gwarancyjna. Standardowymi rozwiązaniami w tym zakresie mogą być: zwrot zapłaconej kwoty, wymianę lub naprawę rzeczy lub też zapewnienie innych usług, np.: bezpłatne holowanie pojazdu w przypadku awarii. Mogą też mieć miejsce różne wyłączenia, np.:

1 dr hab. inż., Państwowa Wyższa Szkoła Zawodowa im. Angelusa Silesiusa w Wałbrzychu, ssalamon@pwsz.com.pl, ORCID ID: 0000-0001-5859-1999 
gwarancja może nie dotyczyć napraw rzeczy dokonanych przez nieautoryzowane stacje obsługi pojazdów.

4. Jaka postać może mieć deklaracja gwarancyjna?

Dokument gwarancyjny powinien być wydany wraz $\mathrm{z}$ rzeczą. Postać dokumentu może przybrać formę: papierową, trwałego nośnika informacji. Informacja zawarta w reklamie rzeczy też ma charakter zobowiązania gwarancyjnego.

5. Jakie moga być obowiazki odbiorcy rzeczy?

Nabywca rzeczy składający reklamację z tytułu gwarancji jest zobowiązany dostarczyć wadliwą rzecz na koszt gwaranta do miejsca jego nabycia. Duże rozmiary lub skomplikowany montaż mogą być powodem odstąpienia od wyżej wymienionej sytuacji, wada będzie usunięta na miejscu u nabywcy. Nabywca udostępnia rzecz gwarantowi, np. lodówkę w domu.

6. Wjakim termin gwarant musi wykonać swoje obowiąki?

W tym względzie, obowiązuje termin wskazany w deklaracji gwarancyjnej. Jeżeli w tym dokumencie nie wskazano terminu, wykonania świadczenia gwarancyjnego należy dopełnić go niezwłocznie lub w ciągu dwóch tygodni. Termin ten biegnie od dnia dostarczenia rzeczy gwarantowi lub zgłoszenia reklamacji.

7. Czy odbiorcy rzeczy przystuguje prawo do reklamacji na zasadzie rękojmi?

Tak przysługują. Deklarowane uprawnienia z tytułu gwarancji są niezależne od uprawnień zawartych $\mathrm{w}$ rękojmi. Wykonanie uprawnień $\mathrm{z}$ tytułu gwarancji nie wpływa na odpowiedzialność sprzedawcy z tytułu rękojmi.

8. Jakie treści powinny być zawarte $w$ deklaracji gwarancyjnej?

Treść deklaracji gwarancyjnej powinna być sformułowana w sposób jasny i zrozumiały, w języku polskim. W szczególności deklaracja ta powinna zawierać następujące dane:

- nazwa i adres gwaranta lub jego przedstawiciela w Polsce;

- czas trwania i zasięg terytorialny ochrony gwarancyjnej;

- uprawnienia przysługujące w razie stwierdzenia wady;

- stwierdzenie „Gwarancja nie wyłącza, nie ogranicza ani nie zawiesza uprawnień kupującego wynikających z przepisów o rękojmi za wady rzeczy sprzedanej”.

\section{Przedmiot badania jakości świadczeń gwarancyjnych [2]}

Konstrukcje okien, niezależnie od materiału, z którego zostaną wykonane, składają się $\mathrm{w}$ większości $\mathrm{z}$ tych samych elementów. My skupimy się jednak na oknach PCV, bowiem to one są najczęściej wybierane przez klientów.

Funkcjonujące w powszechnej świadomości elementy okien potrafi wymienić niemal każdy. Warto jednak zaznaczyć, że ich nazwy mogą się nieco różnić 
w zależności od regionu lub konkretnego producenta. Dlatego w tym artykule posłużono się ogólnie przyjętymi nazwami, zgodnymi z normą PN-EN 12519:2007 „Okna i drzwi. Terminologia”.

Norma ta, co może wielu użytkowników wprawić w spore zdziwienie, opisuje aż trzynaście różnych elementów okna! Wynika to z faktu, że według niej to, co nazywamy ościeżnicą składa się z czterech różnych elementów: ramiaka górnego ościeżnicy, ramiaka dolnego ościeżnicy oraz łączącego je stojaka ościeżnicy. Podobnie wygląda sytuacja w przypadku skrzydła, które składa się z: ramiaka górnego, ramiaka dolnego i bocznego.

Jak zatem widzimy, konstrukcja okna, nawet tego podstawowego, jest bardzo złożona. Poniżej wymieniono i opisano pozostałe elementy okna PCV (por. rys. 1).

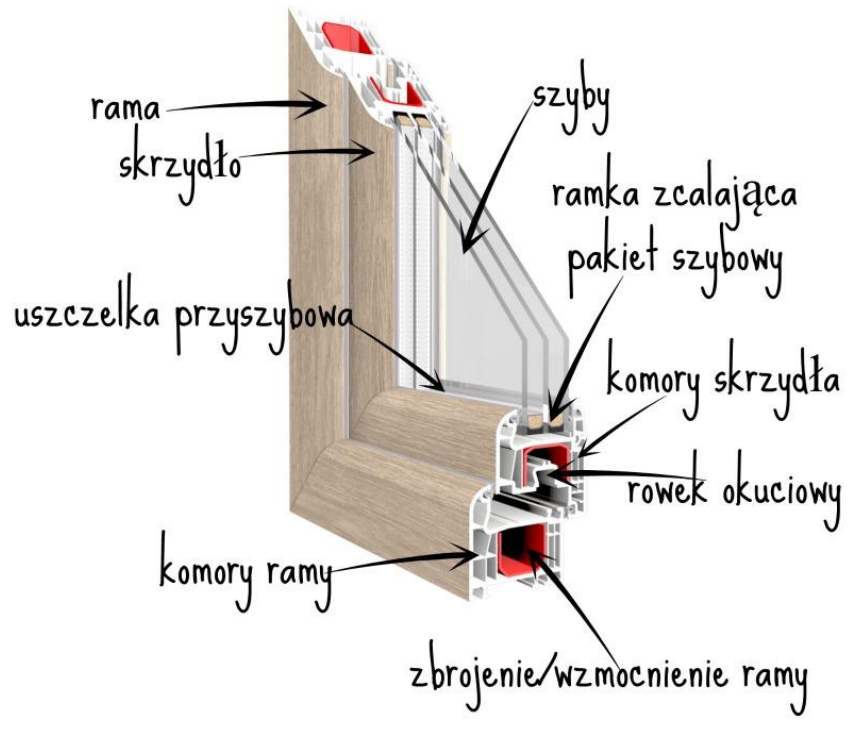

Rys. 1. Elementy sktadowe okien wykonanych z profili PCV

Źródto: [3]

\section{Wyniki badania funkcjonowania systemu świadczeń gwarancyjnych w wytwórni okien PVC [4]}

System obsługi gwarancyjnej i po gwarancyjnej tego przedsiębiorstwa odpowiada wymaganiom określonym $\mathrm{w}$ punkcie 1 niniejszego artykułu. Jednakże w deklaracji gwarancyjnej przedsiębiorstwo to zawarło również specyficzne regulacje 
dotyczące warunków gwarancyjnych, wynikających ze specyfiki oferowanego wyrobu.

Warto zauważyć dużą przezorność w formułowanych wymaganiach przez tego producenta pod adresem nabywcy, według nich wytwórca nie ponosi odpowiedzialności za wady powstałe na wskutek niewłaściwego użytkowania wyrobu (innego niż zaleca instrukcja użytkowania i konserwacji), lub uszkodzeń mechanicznych, chemicznych oraz w przypadku uszkodzeń powstałych na skutek samodzielnego i niewłaściwego montażu przez klienta lub osoby trzecie.

W analizowanym okresie obsługi gwarancyjnej, przedsiębiorstwo to wytworzyło około ćwierć miliona okien. Odnotowano niespełna trzy tysiące zgłoszeń reklamacyjnych, dotyczących serwisu producenta, które stanowią ponad $1 \%$ całkowitej produkcji. Biorąc pod uwagę 5 letni okres produkcji okien, przy standardowym rozliczeniu godzin pracy (jedna zmiana i 24 dni robocze w miesiącu), można zauważyć, że w ciągu dniówki powstaje około 200 okien, przy czym 2 sztuki, statystycznie rzecz ujmując, mogą być wadliwe.

Sytuację w tym zakresie, na przestrzeni 5 lat, ilustruje rys. 2. Na tej podstawie można stwierdzić ciągłą poprawę w zakresie występowania reklamacji okien, aczkolwiek można ją uznać za nie satysfakcjonującą.

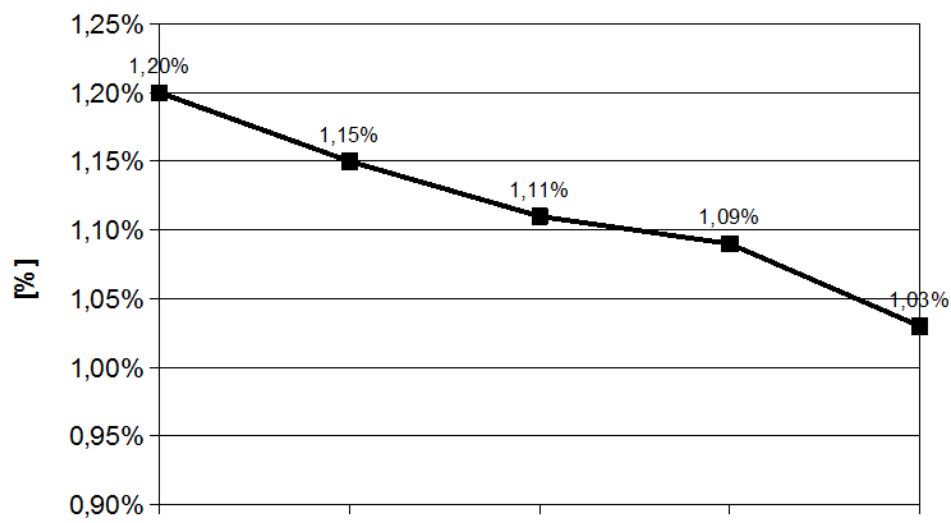

Rys. 2. Ilość reklamacji zgloszonych wytwórcy okien

Źródto: Opracowanie wlasne

Ilość reklamacji uznawanych przez producenta jest wyraźna (por. rys. 3 i 4).

W sytuacji konkretnego przedsiębiorstwa warto podjąć walkę z niezgodnościami w elementach okien zależnych od wytwórcy, na drodze wdrożenia i funkcjonowania systemu zarządzania jakością, zgodnie z norma ISO 18000, 
w długim okresie czasu może on dać znaczące efekty finansowe, w postaci obniżenia kosztów wytwarzania a co zatem idzie utrwalenie konkurencyjnej pozycji rynkowej.

Przedsiębiorstwu temu, $\mathrm{z}$ uwagi na fakt istnienia znaczącego udziału w przyczynach występowania niezgodności, leżących poza gestią przedsiębiorstwem, należy rekomendować położenie nacisku na kontrolę początkową jakości zasobów materialnych, niezbędnych do wytwarzania okien. Zadanie to można zlecić podmiotowi specjalizującemu się $\mathrm{W}$ zakresie kontroli jakości, na zasadzie outsourcingu.

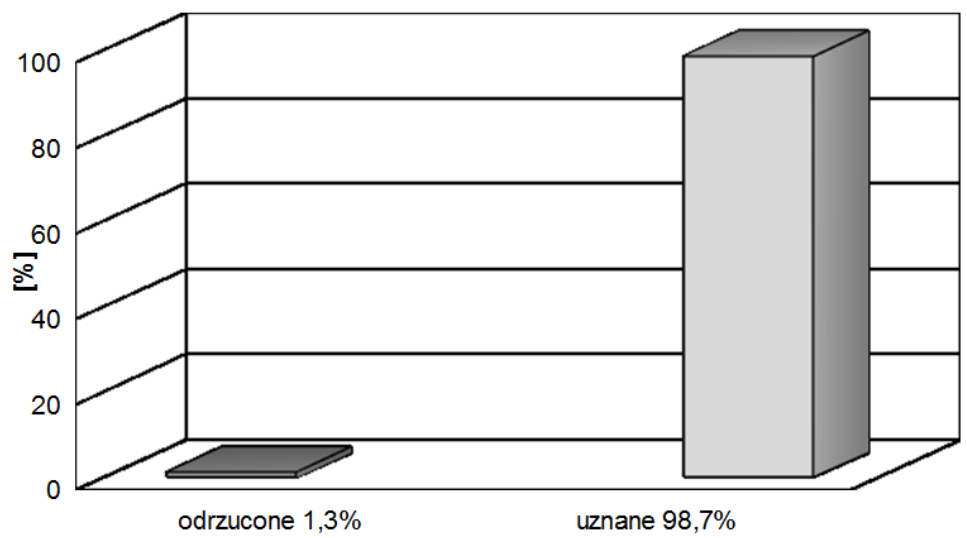

Rys. 3. Ilość uznanych i odrzuconych reklamacji wynikających z wad fabrycznych

Źródło: Opracowanie własne

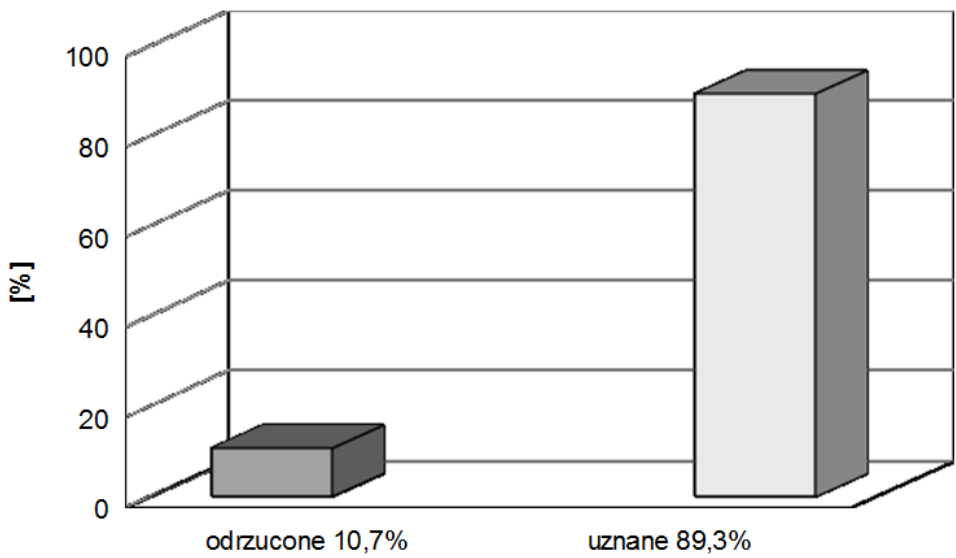

Rys. 4. Ilość uznanych i odrzuconych reklamacji powstalych z przyczyn niezależnych od producenta

Źródto: Opracowanie własne 


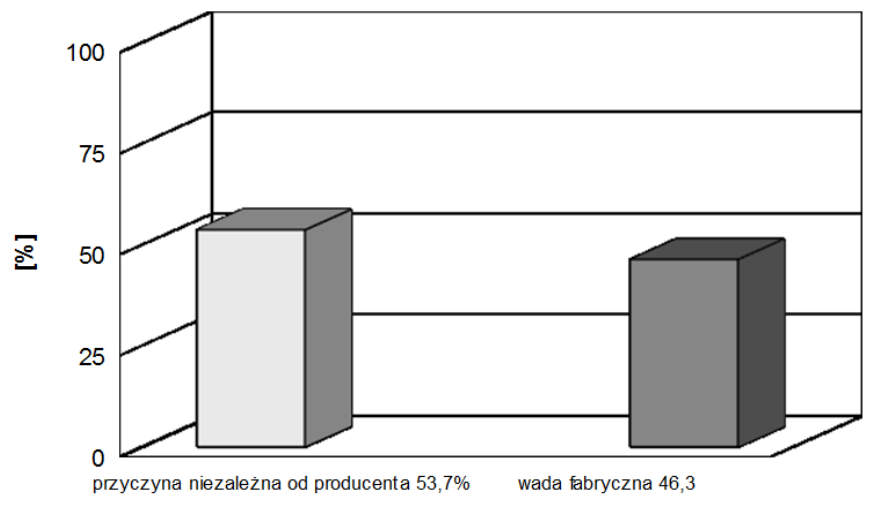

Rys. 5. Udzial reklamacji w zależności miejsca ich powstania

Źródto: Opracowanie własne

Długoletnie doświadczenie tego przedsiębiorstwa, na polskim rynku w branży budowlanej, a co z tym idzie również w obsłudze gwarancyjnej i pogwarancyjnej pozwala wyodrębnić dwie zasadnicze grupy przyczyn reklamacji:

I - przyczyny związane z wystąpieniem usterek z powodu wad fabrycznych, na które nie mają wpływu: sprzedawca, montażysta, klient, użytkownik;

II - przyczyny związane $\mathrm{z}$ wystąpieniem usterek $\mathrm{z}$ powodu działań sfery: sprzedaży, transportu, montażu, użytkownika.

Procentowy udział w/w źródeł w całości zgłoszeń reklamacyjnych przedstawiono na rys. 5. Udziały procentowe obu grup przyczyn reklamacji są niemalże identyczne.

Wady fabryczne wynikają głównie z wad komponentów tj.:

- profili PCV,

- wzmocnienie profilu (w postaci kształtownika stalowego),

- szyby zespolonej,

- okucia obwiedniowego,

- uszczelnienia,

- oraz $\mathrm{z}$ niezgodnościami $\mathrm{w}$ wykonawstwie na poszczególnych liniach produkcyjnych (por. rys. 6). 


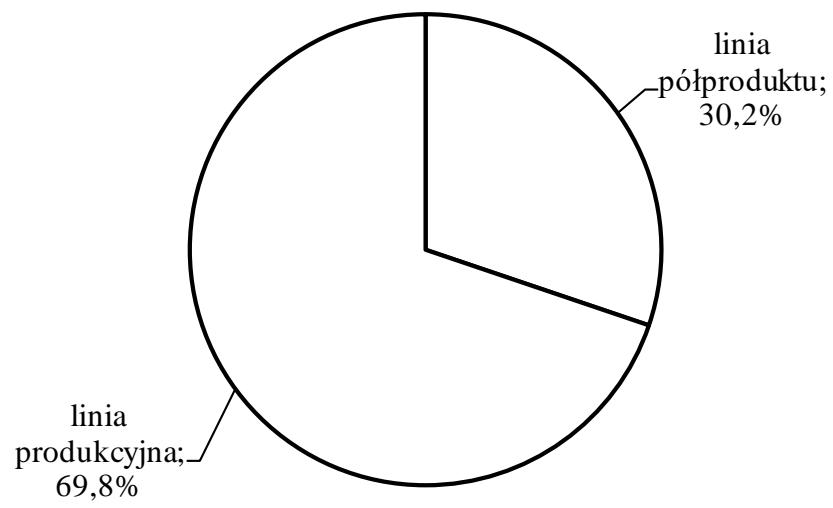

Rys. 6. Udzial reklamacji spowodowanych wadami fabrycznymi na liniach produkcyjnych

\section{okien}

Źródto: Opracowanie własne

Z uwagi na fakt odnotowania znaczących procentowych udziałów w obu grupach przyczyn powstawania wad fabrycznych (por. rys. 6) zdecydowano o konieczności szczegółowej analizy tych przyczyn. Wyniki tej analizy zostały przedstawione na rys. 7 i 8 .



Rys. 7. Udzial reklamacji wynikających z wad poszczególnych pólproduktów okien

Źródto: Opracowanie własne 


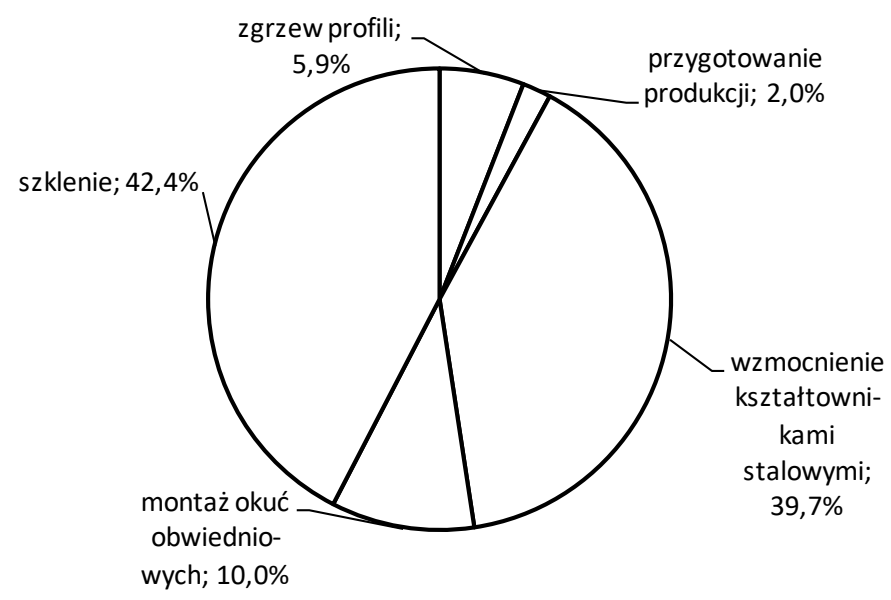

Rys. 8. Udzial reklamacji powstałych na poszczególnych stanowiskach produkcyjnych Źródto: Opracowanie wtasne

Największym problemem są wkłady szybowe (ich udział procentowy wynosi $46,4 \%$ ), oraz okucia obwiedniowe (ich udział procentowy wynosi 42,8\%). Udziały pozostałych półproduktów są nieznaczne. O ile reklamacje wkładów szybowych w postaci zaparowań, zanieczyszczeń, zarysowań, wewnątrz wkładów są niepodważalne i obarczają wytwórcę, to problemy okuć obwiedniowych są często kontrowersyjne, $\mathrm{z}$ uwagi na źródło ich powstawania tj.: nieprawidłowej regulacji i konserwacji, złego montażu, czego konsekwencją jest nieprawidłowa ich eksploatacja. Rzadkością są zerwania elementów zasuwnic i rygli, które również są przyczynami powstawania reklamacji.

Wiele reklamacji wynika $\mathrm{z}$ nieprawidłowości $\mathrm{w}$ funkcjonowaniu poszczególnych linii w procesie produkcji (por. rys. 8) tj.:

- przygotowania produkcji,

- wzmacniania profili kształtownikami stalowymi,

- docinania i zgrzewa profili PCV,

- montażu okuć obwiedniowych,

- szyb zespolonych (tzw. szklenia).

Znaczny udział $\mathrm{w}$ powstawaniu usterek ma nie producent ale pozostali uczestnicy procesu produkcyjno - montażowego tj. strona: sprzedawcy, transportu, montażu czy też ostatecznie użytkownik wyrobu. Wartości ich udziałów $\mathrm{w}$ reklamacjach wynikających $\mathrm{z}$ powodów nie leżących po stronie producenta przedstawia rys. 9. 


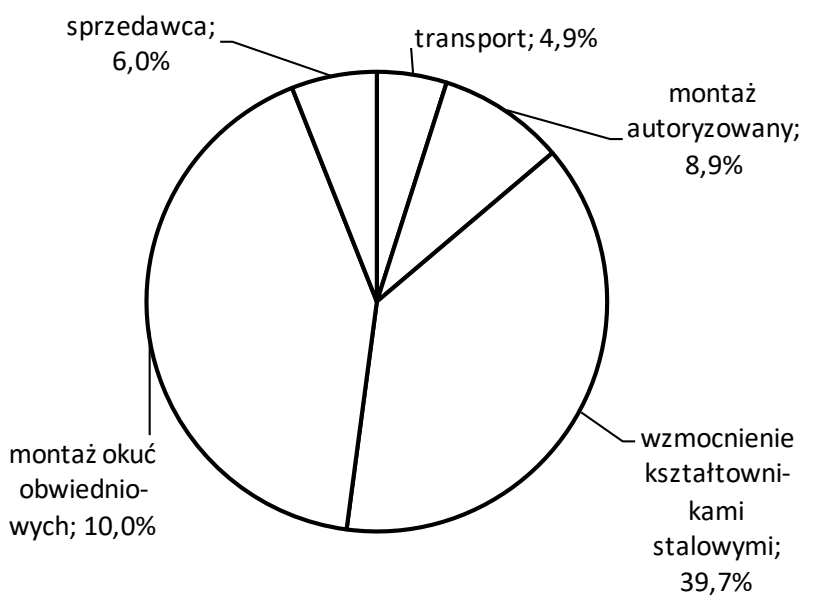

Rys. 9. Udzial reklamacji powstalych poza wytwórca okien

Źródto: Opracowanie własne

\section{Interpretacja wyników badań}

W podsumowaniu analizy obsługi gwarancyjnej, można, stwierdzić, że przedsiębiorstwo preferuje strategię rozstrzygania reklamacji dotyczących wyrobu na korzyść odbiorcy. Niemniej jednak, zdarzały się przypadki nie uznania reklamacji, ich powodami były orzeczenia ekspertów jednoznacznie wskazujących na powstanie usterek z winy użytkownika. Usterki te w szczególności polegały na:

- mechanicznych rysach na zewnętrznych powierzchniach profili i szyb, nie mogące powstać na drodze: sprzedawca - transport - montaż - odbiór,

- ewidentnym zabrudzeniu, poprzez zarzucenie tynkiem okuć obwiedniowych podczas obróbki tynkarskiej, w trakcie montażu wykonywanego przez osoby trzecie, a prowadzące do zrywania listew okuć obwiedniowych,

- braku systematycznej konserwacji uszczelek i okuć obwiedniowych, które doprowadzają do nieszczelności oraz do zerwań lub odkształceń elementów okucia obwiedniowego,

- braku profesjonalnej regulacji.

$\mathrm{Z}$ bezpośrednich rozmów $\mathrm{z}$ serwisantami punktów sprzedaży, jak również z serwisem producenta wynika, że wiele reklamacji rozpatrzonych pozytywnie miało przyczynę niezależną od producenta. Jednakże z uwagi na dobro wizerunku firmy, zostały one usunięte na koszt producenta lub sprzedawcy.

Analizując reklamacje uznano, że warto przyjrzeć się również bliżej ich przyczynom i skutkom jakie za sobą niosą. W konsekwencji jedynym 
niepodważalnym skutkiem są koszty jakie ponosi to przedsiębiorstwo w przypadku ich pozytywnego rozpatrywania. Warto zatem zwrócić szczególną uwagę na konkretne skutki i przyczyny jakie mają miejsce w przypadku zaistnienia wad oraz sposobów ich usunięcia. Mają one źródło, jak wynika z analizy procesu (por. rys. 6), w fazie produkcji, jak również na drodze sprzedawca - użytkownik (por. rys. 9).

Analizując fazę produkcji najwięcej mankamentów, pociągających za sobą roszczenia reklamacyjne, mają miejsce na etapie dopasowywania kształtowników metalowych do profilu PCV, jak również jego mocowania w profilu. Również na linii szklenia odnotowano wiele wad. Tutaj głównym usterką jest brak dostatecznego usztywnienia skrzydła okna, tzn. odpowiedniego zamocowania szyby w skrzydle za pomocą podkładek dystansowych. Nie można zapomnieć o błędach i wadach fabrycznych producenta szyb zespolonych, na które producent okien nie ma wpływu. Dziesięcioprocentowy udział w reklamacjach linii montażu okuć, jest także jest warty zauważenia, tym bardziej iż poprawa polega głównie na odpowiednim dopasowaniu elementów ryglujących ościeżnicę ze skrzydłem, czyli nie wymagających nadmiernych kosztów, a większej uwagi i precyzji montażystów.

Jeżeli przyjrzeć się reklamacjom powstającym na drodze klient - użytkownik, na pierwszy plan wysuwa się docelowy użytkownik, oraz nieautoryzowany montażysta. Często jednak okazuje się, że klienci skarżą się podczas wizyty serwisanta, że nie byli dostatecznie poinformowani, to samo można powiedzieć o wskazówkach, poradach, pouczeniach przekazanych przez sprzedawcę lub montażystę. Zawarte dyrektywy w instrukcji konserwacji i użytkowania okien są niewystarczające lub mało zrozumiałe.

\section{Literatura}

[1] https://prawakonsumenta.uokik.gov.pl/reklamacje/gwarancja/, odczyt dnia 12.04.2019 r.

[2] https://dako.eu/pl/jakich-elementow-sklada-sie-okno-pcv/, odczyt dnia 12.04.2019 r.

[3] http://mihata.pl/okna-energooszczedne-z-cieplym-montazem/. Odczyt, dnia 10.04.2019 r.

[4] Praca zbiorowa. Raport Biura Obsługi Technicznej i Organizacyjnej nt.: Jakość stolarki budowlanej-PCV. Częstochowa 2000. 


\title{
GUARANTEE SERVICE SYSTEM AS A SOURCE OF IMPROVEMENT OF QUALITY OF THE PCV WINDOWS
}

\begin{abstract}
One of the basic conditions for the proper functioning of enterprises is the existence of the warranty and post-warranty service system for the customers in the field of the delivered products. The data obtained from the functioning of this system may be a source of improvement of the product quality management system, in this case PCV windows. This paper presents the data obtained from this system, regarding the causes and effects of the nonconformities of this product.
\end{abstract}

Słowa kluczowe: PCV windows, quality,, warranty vs. surety

Data przestania publikacji do Redakcji: 09.05.2019 Data akceptacji publikacji przez Redakcję: 03.06.2019

DOI: 10.30657/qpi.2019.10.06 